\title{
FURTHER STUDIES ON THE RÔLE OF THE UTERUS IN THE REGULATION OF CORPUS LUTEUM FUNCTION IN SHEEP
}

\author{
B. V. GALDWELL* AND R. M. MOOR† \\ Worcester Foundation for Experimental Biology, \\ Shrewsbury, Massachusetts
}

\section{(Received 21st December 1970)}

It has been well established that removal of the uterus in many mammalian species results in the prolongation of the function and life-span of corpora lutea (Bland \& Donovan, 1966; Anderson, Bland \& Melampy, 1969; Caldwell, Rowson, Moor \& Hay, 1969; Schomberg, 1969; Caldwell, 1970). Furthermore, most evidence suggests that uterine transplantation to ectopic sites can at least partially reverse the extended life-span of the corpora lutea in hysterectomized animals (see Caldwell, 1970, for review). When these studies were extended to test various extracts of uterine tissue or flushings, however, the results were not conclusive. Both success and failure have been reported in the attempt to influence corpus luteum function in hysterectomized animals using extracts of uterine origin given by several routes of administration in various test animals and bioassay systems (Schomberg, 1969; Caldwell, 1970). Previous work has also clearly established the local nature of the 'luteolytic' influence of the uterus since removal of one uterine horn from sheep in which corpora lutea were present in both ovaries resulted in regression of the luteal tissue in the ovary which was still connected to the remaining uterine horn, and maintenance of the corpus luteum in the ovary without any direct tissue continuity with uterine tissue (Inskeep \& Butcher, 1966; Ginther, 1967; Caldwell et al., 1969). Evidence has been presented in other species that the pathway by which this local effect may be mediated to the ovary is by way of a local vascular connection (Howe, 1965; Barley, Butcher \& Inskeep, 1966; Clemens, Minaguchi \& Meites, 1968). The present investigation was designed to test this hypothesis by infusing freeze-dried uterine venous plasma, withdrawn at different times during the oestrous cycle of sheep, into the ovarian artery of intact sheep on Day 8 of the normal 16-day cycle and studying the effects of the infusion on corpus luteum function and the length of the ensuing oestrous cycle.

From each of six sheep, $500 \mathrm{ml}$ of blood were collected from the uterine veins on the 14th day after the onset of oestrus. Blood was also collected from the jugular vein of these animals and from the uterine vein of three sheep 8 days

* Present address: Yale University School of Medicine, Department of Obstetrics and Gynecology, 333 Cedar Street, New Haven, Connecticut 06510, U.S.A.

$\dagger$ ARC Unit of Reproductive Physiology and Biochemistry, 307 Huntingdon Road, Cambridge, England. 
after the last appearance of oestrus. The plasma was freeze dried after centrifugation and powdered in a Waring blender. The material was stored at $0^{\circ} \mathrm{C}$ until ready for use and then infused into intact ewes again 8 days after the last appearance of oestrus. Only seven animals are reported in this investigation, but many other attempts were made which were discontinued because of technical difficulties in maintaining a constant flow of the infusion fluid into the ovarian artery. To attest that the infusion was entering the ovary, a small amount of methylene blue was periodically injected into the fluid and the resulting accumulation of colour in the ovary was confirmatory that the materials were reaching the desired site. Table 1 lists the amounts of material infused and the duration of the experiments.

At the start of the infusion and at its termination, blood was collected from the ovarian veins. Progesterone was measured using the u.v. spectrophotometric method of Rowlands \& Short (1959), with the single exception that a thin-layer separation of the progestins was made instead of the paper system described by these authors.

\section{TABLE 1}

THE EFFECTS OF FREEZE-DRIED SHEEP PLASMA INFUSED INTO THE ARTERY OF INTACT SHEEP ON THE 8TH DAY OF THE OESTROUS CYCLE

\begin{tabular}{c|cc|c}
\hline $\begin{array}{c}\text { Source of freeze- } \\
\text { dried plasma infused } \\
\text { (6- to 8-hr infusion) }\end{array}$ & $\begin{array}{c}\text { Ovarian venous progesterone }(\mu \mathrm{g} / 100 \mathrm{ml}) \\
\text { Before } \\
\text { infusion }\end{array}$ & $\begin{array}{c}\text { After } \\
\text { infusion }\end{array}$ & $\begin{array}{c}\text { Length of oestrous } \\
\text { cycle } \\
\text { (days) }\end{array}$ \\
\hline Day 8 uterine vein & 125 & 105 & 15 \\
$(500 \mathrm{mg} / \mathrm{hr})$ & 85 & 100 & 17 \\
Day $14 \mathrm{uterine}$ vein & 145 & 85 & 10 to 11 \\
$(500 \mathrm{mg} / \mathrm{hr})$ & 165 & 80 & 10 to 11 \\
& 110 & 65 & 11 to 12 \\
Day $14 \mathrm{jugular}$ vein & 135 & 145 & 15 \\
$(500 \mathrm{mg} / \mathrm{hr})$ & 180 & 160 & 16 \\
\hline
\end{tabular}

The onset of behavioural oestrus was determined using vasectomized rams fitted with marking crayons in a harness.

Ovarian venous plasma progesterone levels fell by about $50 \%$ during the 6to 8-hr infusion of 14-day freeze-dried plasma to sheep on the 8th day of the cycle. These experimental animals returned to oestrus between 48 and $72 \mathrm{hr}$ after the cessation of infusion, that is on the 10th or 11th day of the cycle (Table 1). In the control group of animals which received freeze-dried plasma prepared from sheep 8 days after oestrus, no significant drop in the progesterone levels was noted, nor was there any influence on the length of the ensuing oestrous cycle. The same was found to be true of animals receiving freeze-dried plasma prepared from jugular venous blood taken from sheep on the 14th day of the cycle.

The rapid drop in the progesterone level during the infusion of 14-day freeze-dried plasma and the dramatic shortening of the cycle length are both highly significant indices of early corpus luteum regression in the experimental animals. Regression of the corpus luteum in intact untreated sheep takes 12 to $24 \mathrm{hr}$ and, thus, a $50 \%$ drop in the progesterone levels of the experimental 
ewes during the 6- to 8-hr infusion period is probably similar to the rate of luteal regression at the end of the cycle. It should be noted, however, that the appearance of behavioural oestrus in the three experimental sheep was not as clearly defined as in the control animals, probably suggesting that progesterone levels may not have continued to fall as rapidly as in normal animals.

The concept that uterine plasma acquires selective lytic properties around the critical 14th day of the cycle is supported by our observations that the corpus luteum is rapidly destroyed by the infusion of 14-day uterine plasma but is not affected by similar infusions of either 8-day uterine plasma or 14-day plasma obtained from the jugular vein. McCracken, Baird \& Goding (1971) have recently reported similar observations and have suggested that the lytic substance may be carried directly to the ovaries in sheep through a 'counter current' exchange between the uterine vein and ovarian artery. The ovarian artery runs directly along the uterine vein in this species and Goding has shown that merely separating the ovarian artery from the uterine vein, and placing a piece of omentum between the two vessels results in prolonged luteal function (McCracken et al., 1971). Our results are consistent with this theory and experiments in progress will be directed towards the isolation and identification of the 'luteolytic' substance. The recently reported effects of prostaglandins and their possible association with the mechanisms for regulating luteal function make these compounds of considerable interest in this connection (Pharriss, 1971; Horton, Thompson, Los, Jones, Davis \& Poyser, 1971; McCracken et al., 1971).

\section{REFERENCES}

Anderson, L. L., Bland, K. P. \& Melampy, R. M. (1969) Comparative aspects of uterine luteal relationships. Recent Prog. Horm. Res. 25, 51.

BARLEY, D. A., BUTChER, R. L. \& INSKeEP, E. K. (1966) Local nature of utero-ovarian relationship in the pseudopregnant rat. Endocrinology, 79, 119.

Bland, K. P. \& Donovan, B. T. (1966) The uterus and the control of ovarian function. In: Advances in Reproductive Physiology, Vol. I, p. 179. Ed. A. McLaren. Academic Press, London.

CALDWELL, B. V. (1970) Uterine factors influencing corpus luteum function. In: Advances in Biosciences, Vol. 4, p. 399. Ed. G. Raspe. Pergamon Press, Vieweg.

Caldwell, B. V., Rowson, L. E. A., Moor, R. M. \& HAY, M. F. (1969) The utero-ovarian relationship and its possible role in infertility. J. Reprod. Fert. Suppl. 8, 59.

Clemens, J. A., Minaguchi, H. \& Mertes, J. (1968) Relation of local circulation between the ovaries and uterus to lifespan of corporalutea in rats. Proc. Soc. exp. Biol. Med. 127, 1240.

Ginther, O. J. (1967) Local utero-ovarian relationships. F. Anim. Sci. 26, 678.

Horton, E. W., Thompson, C. J., Los, M., Jones, R. L., Davis, H. A. \& Poyser, N. L. (1971) Release of prostaglandins. Conference on Prostaglandins. Ann. N.Y. Acad. Sci. (In press).

HowE, G. R. (1965) Influence of the uterus upon cyclic ovarian activity in the guinea pig. Endocrinology, 77,412 .

INSKEEP, E. K. \& BUTCHER, R. L. (1966) Local component of utero-ovarian relationships in the ewe. 7. Anim. Sci. 25, 1164.

McGracken, J. A., Baird, D. T. \& Goding, J. R. (1971) The study of ovarian function in the ewe by autotransplantation to the neck. Recent Prog. Horm. Res. 27, (In press).

Pharriss, B. B. (1971) Prostaglandin induction of luteolysis, Conference on Prostaglandins. Ann. N.Y. Acad. Sci. (In press).

Rowlands, I. W. \& Short, R. V. (1959) The progesterone contents of the guinea-pig corpus luteum during the reproductive cycle and after hysterectomy. F. Endocr. $19,81$.

SchomberG, D. W. (1969) The concept of a uterine luteolytic hormone. In: The Gonads. Ed. K. W. Mckerns. Appleton-Century-Crofts, New York. 